\title{
Environmental Risks and Precautions of Chinese Enterprises' Foreign Investment in the Context of Green Belt and Road Initiative
}

\author{
Xiangshi Mao \\ International Business School \\ Yunnan University of Finance and Economics \\ Kunming, China \\ 809390193@qq.com
}

\begin{abstract}
Since the Belt and One Road Initiative was put forward, Chinese enterprises have further increased their investments in countries and regions along the route. In recent years, global awareness of environmental protection has generally risen, and the environmental protection needs of countries along the route have also increased. China further puts forward the concept of Green Belt and Road Initiative to strengthen the protection of the ecological environment of the countries and regions along the route. Therefore Chinese enterprises must pay more attention to environmental protection issues in their outward investment. This article analyzes the environmental risks that Chinese companies may face in their foreign investment in the context of Green Belt and Road and proposes countermeasures and suggestions.
\end{abstract}

Keywords-the Green Belt and Road Initiative; foreign investment; risks; precautions

\section{INTRODUCTION}

In 2013, President Jinping Xi proposed the Belt and Road Initiative (the Silk Road Economic Belt and the 21st Century Maritime Silk Road initiative), holding high the banner of peace and development; adhering to the principles of mutual business, sharing, and joint development; aiming to promote the political, economic, and cultural exchanges and cooperation with the countries along the route; creating a common interest community, a destiny community, and a responsibility community with political mutual trust, economic integration, and cultural inclusion. The proposal of the Belt and Road Initiative has received great attention from the international community. Countries along the route have responded positively and have made remarkable achievements. In 2016, the total import and export volume of China's enterprises along the Belt and Road route was 6251.7 billion Yuan, accounting for $25.6 \%$ of China's total import and export volume; direct investment in the 53 countries along the route was US\$ 14.53 billion, accounting for $8.5 \%$ of China's total foreign direct investment.

With the increasing awareness of global environmental protection, sustainable development and green development have become the goals pursued by countries, especially countries along the Belt and Road route. First, most of the countries along the route are developing countries. In the past, one-sided pursuit of development and ignorance of environmental protection have caused serious damage to the ecological environment. Nowadays, countries along the route are facing environmental problems such as industrial wastes pollution, air pollution, and land desertification. Most of the regions are located in inland areas, and there are few precipitations and deserted areas far away from the ocean. The ecological environment is fragile. If development is not focused on conservation, it will cause inestimable damage to the ecological environment.

On August 17, 2016, Jinping $\mathrm{Xi}$ proposed to focus on building the Green, Healthy, Intellectual, Peaceful Belt and Road. On April 26, 2017, the Ministry of Environmental Protection, the Ministry of Foreign Affairs, the Development and Reform Commission and the Ministry of Commerce jointly issued the "Guiding Opinions on Promoting the Construction of the Green Belt and Road Initiative."

In the context of the Green Belt and Road, Chinese enterprises must closely follow the policies and laws of environmental protection in foreign investment. First of all, this is the need for development of the company itself. Nowadays global awareness of environmental protection has risen along with advances in environmental protection science and technology, and environmental protection has also been incorporated into the scope of competition among enterprises. Green, energy-saving and environmentally friendly companies are favored by markets around the world. Enterprises with high energy consumption and high pollution will be ruthlessly eliminated. Secondly, in the investment field, especially foreign investment, neglecting environmental protection issues will cause investment risks and even lead to investment failures, causing huge losses to enterprises. In summary, in the context of Green Belt and Road Initiative, this paper analyzes the potential environmental risks of Chinese enterprises' foreign investment, and proposes countermeasures and suggestions.

At present, most of the researches on environmental protection in China's foreign investment are based on the macro-national government level. Nan Lee [1] proposed that there is a clear conflict between the ecological environment 
vulnerability along the Belt and Road Initiative route and the unbalanced regional economic development; the legal system of domestic environmental protection is immature and foreign environmental protection legal standards are different. Yingcong Tian [2] believes that regional cooperation platforms in the field of environmental protection in countries along the Belt and Road Initiative are still far from being mature. Regional multilateral or bilateral cooperation mechanisms are not feasible; different stages of development determine the differences in environmental protection positioning. Enyuan Liu [3] proposed that foreign investments of Chinese enterprises lack legislative restrictions, standards and accountability mechanism on environmental protection.

Many scholars are also dedicated to research China's environmental protection measures for outward foreign investment in the Belt and Road Initiative. Dongmei Guo and Yujuan Wang [4] proposed that China should implement the guidelines and policies, such as "Guiding Opinions on Promoting the Construction of the Green Belt and Road" and "the Belt and Road Initiative Ecological Environmental Protection Plan", to guide Chinese enterprises; promote the development of environmental protection service industries; provide necessary environmental consultations, assessments and other services for Chinese companies; accelerate the construction of the Belt and Road eco-friendly big data service platform, Strengthen information support and improve the ability to prevent risks in the ecological environment. Ran Jie and Jun Zhou [5] believe that a policy-exchange platform of the Green Belt and Road Initiative should be established to enhance the communication of national policies along the route innovate the green financial mechanism to cultivate a green financial market of the Belt and Road Initiative, and use state funds as a guide to encourage commercial equity investment funds and social funds to participate in the construction of key projects. Luozhong Wang and Yijun Zhang [6] proposed to encourage to diversify the participants, deepen the international environmental protection cooperation, clarify environmental responsibilities and resolve environmental disputes through multi-party agreements; carry out eco-environmental demonstration projects, actively publicize and share China's ecological concepts and experience of green development, and support the development of national environmental protection capabilities along the route so that countries along the route could participate in cross-border cooperation in environmental protection and work together to create a regional green industrial chain.

As for the environmental protection of Chinese enterprises in foreign investment, Hongkai Wang [7] believes that companies have weak corporate social responsibilities and do not pay attention to the public relations with the local people in the host countries along the route. They should implement the concepts of sustainable development and humanism. Enterprises should consciously perform their environmental social responsibilities. Min Zhang and Xueyan Zhu [7] proposed that the enterprises in the construction of the Belt and Road Initiative project will encounter legal risks in environmental protection during their foreign investment operations. And the environmental protection regulations of host countries are weak and the Chinese enterprises' environmental awareness is not strong. Therefore, Chinese companies must carry out environmental impact assessments, prepare an environmental impact assessment report, and plan in advance for potential environmental problems. Xiong Lee [8] believed that international investment may face environmental protection legal risks of "green investment protectionism". Chinese enterprises should establish environmental awareness, pay attention to the environmental management of production, carry out projects in accordance with environmental standards of host countries; actively participate in environmental protection charity activities, and create a good image of enterprise. Enterprises should also establish environmental protection legal culture; pay attention to the host country's environmental protection judicial cases; establish strict rules and regulations for the protection of the host country's environment to conduct corporate activities in accordance with the host country's environmental protection law.

\section{ANALYSIS OF ENVIRONMENTAL RISKS}

\section{A. Green Protectionism Risks}

The governments of the host countries along the Belt and Road Initiative route generally have two basic considerations for the investment of Chinese enterprises. On the one hand, they encourage investment, and expects Chinese companies to provide capital and technical support to drive economic development; on the other hand, it is worried that investment by Chinese companies will cause wastes of resources and destructions of the environment. Therefore, all countries also hold different degrees of protectionist tendencies toward investments from Chinese companies. This kind of green protectionism includes environmental laws and regulations, administrative procedures or enforcement procedures that impose restrictions on the investment of Chinese enterprises, as well as domestic arrangements that actually have restrictions. This article mainly analyzes the risks from two aspects: green barriers of investment access and non-national treatment.

\section{1) Green barriers of investment access}

Green barriers originally meant that in the field of international trade, a country issued trade protection measures for the import of foreign products or services by enacting and implementing strict environmental protection regulations and harsh environmental protection technical standards. Its main forms are green technical standards, green environmental signs, green quarantine systems etc. It is characterized by extensiveness, concealment, and ruggedness. Today, in transnational investment, the host country also adopts green barriers for the purpose of protecting its ecological environment and limiting foreign investment, expressed as investment restrictions, requirements for environmental protection equipments and environmental assessment of investment projects.

In order to meet these barrier requirements, there may be several risks:

- Host country limits investment in the name of environmental protection, so that enterprises can not enter the field of their core competitiveness. For example, if construction projects are allowed to enter, 
but the production of construction materials attached to them are not approved; paper manufacturers are only approved with the processing part and are not approved with timbers cutting. Otherwise host country imposes additional conditions on the investment, resulting in weakened corporate competitiveness. For example, the construction project with additional conditions for the construction of surrounding traffic infrastructure.

- To meet the requirements, enterprises upgrade environmental protection equipments or adopt new environmental protection technologies resulting in excess environmental protection expenditures.

- In order to obtain legal entry qualifications, it is necessary to get through its prescribed procedures which takes time or delays the investment period, even misses the best investment time.

\section{2) Non-national treatment}

The unfair non-national treatments that Chinese enterprises may face when invest in the countries along the Belt and Road Initiative route mainly because the host country for the purpose of protecting the environment and improving the competitiveness of domestic companies. They also adopts different arrangements between domestic companies and foreign investment in regulatory compliance, environmental protection standards, and environmental protection taxes which tend to adopt stricter supervision and higher environmental standards for foreign investment or grant subsidies to domestic companies. These measures will relatively reduce the competitiveness of Chinese enterprises and cause investment risks.

\section{B. Risks of Environmental Laws and Legal Environment}

1) Legal risks of host country's environmental protection laws

The legal systems of countries along the Belt and Road Initiative route are different China's. Most of them belong to common law countries, while China is a civil law country. And the specific national conditions are different so that the degrees of legislation completeness are different. Therefore, there are major differences in legal standards and procedures on environmental protection. In addition, due to the continuous environmental issues caused by foreign investments, many countries have strengthened the formulation of laws and regulations on environmental protection to further regulate foreign investment and protect their ecological environment. If Chinese companies fail to fully and deeply understand the provisions of the host country's environmental protection laws in their foreign investment, they will bring about risks.

Take Myanmar as an example. In 2012, Myanmar enacted the Environmental Protection Law to improve domestic environmental protection laws. In addition, Myanmar promulgated other environmental protection laws, such as the Myanmar Animal Health and Development Law, Burma Plant Inspection and Quarantine Law, Myanmar Fertilizer Law, and Myanmar Open Space, Idle Land, Wasteland Management Regulations, Myanmar Forest Law and Myanmar Wildlife and Natural Regional Protection Law. The emphasis on environmental protection is self-evident. For instance, in the application process of a investment, the Investment Committee (MIC) requires the Department of Environmental Protection and the Department of Forests to provide independent assessments and recommendations for the project. In the list of Types of Foreign Investment Economic Activity Regulations, the pre-assessments of environmental assessment that economic activities required are separately listed as a sub-list. In this sub-list, mining production, water power, and coal-fired power, production of chemicals and, battery manufacturing, steel industry, cement manufacturing, petrochemical industry, etc. have all been mentioned.

\section{2)Risks of changes in the environmental protection law of} the host country

The overseas investment of Chinese enterprises along the Belt and Road Initiative route is a long-term process. With the increasingly strict requirements of the environmental protection and the improvement of the legal system, there are more stringent trends for foreign investment in environmental protection standards, policies, and laws. Due to those changes, investments that may initially meet those requirements will no longer meet new environmental standards, which will hinder the continued investment.

3) Risks of lacking in the host country's environmental protection law

Most of the countries along the Belt and Road Initiative route are developing countries, and the laws on environmental protection are incomplete or even lacking. Due to lack of legal constraints, companies lack implementation standards or reduce environmental protection standards for reasons such as cost savings. But the absence of such laws does not mean that foreign investment is actually unconstrained. With the rising social environmental awareness, the environmental protection requirements of the public and social groups are higher than existing laws, and that may cause public protests.

\section{4) Risks of host country's overall legal environment}

- The overall domestic legal environment and some special legal traditions and customs of the host countries along the Belt and Road Initiative route create many uncertainties for China's outward foreign investment. These uncertainties may also evolve into risks, such as the legal system, the degree of justice and other aspects of justice. Taking Myanmar as an example, due to its important geographical location, many Chinese enterprises have entered Burma to carry out infrastructure construction. There have been many examples of investment failures caused by legal environment risks. From the experience of Chinese companies in investing in Myanmar and the overall legal environment in Burma which reflect the overall legal environment in Myanmar, there are the following characteristics:

- The legal awareness is not strong.

- The legal provisions and the specific implementation lack transparency. 
- The military regime and local forces damage the independence of the judiciary.

- The protection of basic human rights is not enough.

\section{Risks of Environmental Social Responsibility}

Social responsibility refers to an organization's responsibility to the society. It usually refers to the social obligations that the organization undertakes above the organization's own goals. It exceeds the legal and economic obligations that the organization requires. The social responsibility defined by the Chinese Academy of Social Sciences "Corporate Social Responsibility Report" refers to the assessment of the level of corporate social responsibility from four aspects: responsibility management, market responsibility, social responsibility, and environmental responsibility. Social responsibility is the requirement of organizational management ethics. It is entirely an organization's voluntary behavior out of obligations. Social responsibilities include corporate environmental protection, safe production, social ethics, and public interests basically.

Environmental protection is an increasingly important factor in social responsibility. With the development of global multinational investment and the increasing awareness of environmental protection in various countries, assuming social responsibility has become an important factor affecting foreign investment.

At present, in the process of Chinese enterprises' foreign investment in environmental protection and social responsibility, they generally face three main stakeholders: the host government, the host people, and non-governmental organizations. If they can not deal with the relationship between these three stakeholders, it may cause environmental responsibility risks, and even affect the investment activities.

\section{1) Risks from government of host country}

The governments are important stakeholders in foreign investment because they are official representatives of countries or regions. The roles played by the governments in different institutional countries and different ideological countries or regions are not the same. Sometimes reach agreements with governments can really promote the implementation of the investment, and sometimes they play limited roles, so that neglecting, despising or over-emphasizing and relying on the roles of the local governments of the host countries may cause risks.

Besides, when the governments approve foreign investments they may set "soft conditions" of corporate social responsibility for the purpose of improving local infrastructure.

\section{2)Risks form people of the host country}

The host people are important stakeholders either. The host people are divided into two kinds. One is the direct stakeholder, such as residents of the project site or competitors, consumers, raw material suppliers of products and services, etc. The other is indirect stakeholder, such people are not directly connected with the project, but for other purposes they influence the project through social media. If you do not meet the environmental responsibility requirements of the direct stakeholders it will directly affect the implementation of the project. If companies ignore the voices of indirect stakeholders they may also trigger public opinion and hinder investment.

\section{3) Risks from environmental non-governmental organizations}

In 1952, the UN Economic and Social Council defined in its resolution that "in which all international organizations are not established by agreements between governments can be regarded as non-governmental organizations," and now refer to those that are social organizations of public functions which are independent from governments.

With the development of non-governmental organizations, they play important roles in international investments. Nongovernmental environmental protection organizations, including international environmental non-governmental organizations and environmental NGOs within the host countries, pay attention to environmental protection in international investments of developing countries, oppose investment behavior that does not meet their requirements by exert influence on the government and people to achieve its appeal.

Contemporary environmental NGOs also have some new features. First, the motives of them are complex, and sometimes their actions even involve certain political factors. Second, they have strong influence than before; sometimes even directly affect the project. If a Chinese company disregards the roles of environmental NGOs in foreign investments, it will cause environmental responsibility risks.

\section{Risks of Improper Environmental Protection Dispute Resolution}

\section{1) Disadvantageous position}

When enterprises have environmental disputes in investment, compared with the government, people of host countries and the social groups, enterprises are often in passive situations. Being in a vortex of pressure, it is easier to lead to an unfavorable result.

\section{2)Risks of lacking legal solutions}

On the one hand, Chinese enterprises lack awareness of using legal rights to protect their foreign investment. If Chinese companies do not deal with environmental disputes in a proper way, they will receive huge environmental protection fines or investment activities will be terminated which resulting in irrevocable investment losses. When dealing with such disputes, Chinese enterprises often have the notion of "solve it with costs privately". This kind of solution not only allows enterprises to bear huge expenditures but also does harms to the establishment of a good image of the enterprise, and it is not conducive to the implementation of future investment.

On the other hand, Chinese enterprises can not flexibly use legal tools to resolve environmental disputes. There is a lack of practical experience and ability in using international legal rights. There are not any successful cases of using transnational legal rights. Enterprises often focus only on economic activities and ignore the importance of legal responses to disputes. Due to the lack of talents who are proficient in transnational laws 
and procedures, it is difficult to safeguard our legitimate rights and interests as far as possible in cross-border negotiation and arbitration. It can be foreseen that as the general awareness of environmental protection in many countries the requirements for environmental protection become more stringent. And Chinese enterprises may face more and more environmental disputes in foreign investments.

\section{PRECAUTIONS OF ENVIRONMENTAL RISKS}

\section{A. Applying Environmental Legal Tools Comprehensively}

1) In-depth investigating the environmental laws and legal environment of host country

A special group for environmental law was established to carry out special research on the laws of the host country on environmental protection and to conduct specific analysis on the environmental protection risks. Employ talents who are proficient in environmental laws of host country to ensure localization of understanding of environmental protection laws and avoid misunderstandings.

In addition, it should be recognized that the legal environment of a country has important implications for the implementation of environmental laws. In the previous investigation of the host country's environmental protection law, it was necessary to add in the study of the overall legal environment and legal customs of the host country. Enterprises should also focus on analyzing the judicial cases, summarize the characteristics of the host country's legal environment from past cases and compile detailed reports of environmental protection laws and legal environment.

2) Combining the host country's, China's environmental laws and international environmental conventions

With the continuous increasing global and regional economic cooperation, the investments in the host country are not only regulated by the laws and policies of the host country but also constrained by home country's policies and laws and international environmental conventions. Enterprises should comprehensively incorporate the regulations of three-party into a unified restricted system of environmental protection for foreign investment and strictly abide by it.

\section{B. Improving Environmental Protection Capabilities}

\section{1) Carring out environmental risk assessment}

Before the launch of foreign investment, carry out a comprehensive assessment of environmental risks and invite environmental experts from both China and the host countries to participate in the comprehensive evaluation of materials, technologies, products, and construction site selection.

\section{2) Adding environmental protection clauses to the} contract

In the signing of contracts for foreign investment, environmental protection clauses must be added.

- It is necessary to clarify the environmental responsibility of all parties involved in the investment;
- Set up a stability clause, which can be used to seek compensation or renegotiate with the contracting parties on the terms of the investment contract when the environmental protection standards change.

- Stipulate the ways of solving environmental disputes.

\section{3) Making an environmental protection plan}

Make a feasible environmental protection plan based on policies and laws of home country and host countries, bilateral and multilateral international treaties which include environmental protection technologies, equipment, procedures, costs and process management.

\section{4) Upgrading environmental protection technology}

To achieve the host countries' environmental protection standards, companies need green production equipments and technologies. Enterprises should abandon the production methods with high energy consumption and high pollution and innovate, improve or purchase low-carbon, high-efficiency technologies and equipments.

5) Cooperating with professional service suppliers of environmental protection

Environmental protection is also becoming more and more specialized. The environmental protection service suppliers are enterprises that specialize in environmental protection and provide other companies with services such as environmental protection management and pollutants purification. If an enterprise wants to improve environmental protection capabilities in the short term but lacks related technologies, equipments and experience in environmental protection, it is necessary to outsource environmental protection work to service suppliers of environmental protection.

\section{Actively Fulfilling the Environmenta Social Responsibility}

1) Incorporating environmental social responsibility into the plan

In the planning period of investment activities, the factors of fulfilling social responsibility of environmental protection should be considered. Based on the overall investment project, enterprises decide the scale and ways of social responsibility for environmental protection. On the one hand, planning to implement environmental social responsibility is beneficial for implementation of investments. On the other hand, incorporate environmental social responsibility into the project plan, set a budget for environmental social responsibility to control costs and minimize the adverse impacts.

2) Combining the needs of government, people and investment

The fulfillment of environmental social responsibility is manifested as increases in costs which has a negative impact on investment. Therefore enterprises must pay attention to control costs when fulfill environmental social responsibility. Enterprises should determine the way to fulfill environmental social responsibility in the goal of facilitating investment.

This fulfillment of environmental social responsibility should have strong links with the project, such as the shareholders: local people, employees, consumers, suppliers. If 
there is no close relationship between the fulfillment of environmental social responsibility and investment, it will not promote the implementation of investments. In some cases, social responsibility caused by environmental protection but the social responsibilities that host government and the public expect the enterprises to fulfill are not directly related to environmental protection. This requires companies to try their best to negotiate or persuade them to compromise on the expectations and to choose the final solutions supported by the three parties.

3) Establishing good relationships with environmental NGOs

First of all, recognize the influence of non-governmental organizations. Enterprises should communicate with environmental NGOs actively and introduce the relevant measures for the environmental protection of the project. If they are doubtful about the environmental protection measures of our investment, we must explain it. When there are opinions and suggestions about environmental protection from environmental NGOs, we should pay attention to them and give answers after internal consultation to avoid the aggressive behaviors of environmental NGOs that may affect the investment.

\section{Resolving Environmental Disputes Properly}

1) Inviting multiple parties to participate in the solution

Enterprises should maintain effective communications with international and regional environmental cooperation organizations and platforms, especially the regional cooperation platforms that China has participated in. International and regional environmental protection organizations and platforms play an important role in solving international environmental disputes: the formulation and implementation of inter-government policies, guidance and control of the investment behavior of enterprises in the region, and coordination of the regional government, enterprises, and people's relations. Actively establish a good relationship with these multinational platforms to obtain the most comprehensive and reliable environmental protection policies and seek environmental protection advices in the process of foreign investment so that enterprises can keep foreign investments in conformity with requirements of environmental protection.

In solving environmental disputes, companies should invite representatives of the home country's foreign investment management agency, host country's environmental protection agency, regional cooperation organization or environmental protection agency, legal experts in environmental protection to participate in the dispute resolution process to seek fair and equitable results to the greatest extent possible.

\section{2) Solving through legal channels}

First, enterprises must recognize the economic and social significance of resolving environmental disputes through legal means and avoid high-cost reconciliation or unequal treatment. Then enterprises should seek legal solution to environmental disputes, such as arbitration litigation.
The introduction of international talents, especially international legal talents, will strengthen the capacity for the legal settlement of environmental disputes. Enterprises should also seek legal help from legal advice centers and offices in China and the host country and research on environmental protection laws and legal tools. In addition, learning from the experience of other multinational corporations to improve legal capacity for environmental disputes is an important measure.

\section{ACKNOWLEDGMENT}

First of all, I want to express my gratitude to my tutor Professor Jiawu Gan who helped me a lot in setting logic structure when I wrote this paper. Secondly, sincerely thank my teacher Professor Lairu Lee for helping me choose this topic which is pratical and significant.

Thank all the people who spport me in academic researches.

\section{REFERENCES}

[1] Nan Lee, "Environmental Problems and Countermeasures in implementation of the Belt and Road Initiative," New Western, vol. 9, pp. 41-42, 2017

[2] Yingcong Tian, "Ecological Environment Protection of Countries along the Belt and Road Initiative Route," Review of Economic Research, vol. 4, pp.68-73, 2017

[3] Enyuan Liu, "Research on the Present Situation and Countermeasures of Chinese Enterprises' Foreign Investment," Theory and Modernization, vol.11, pp. 108-112, 2015.

[4] Dongmei Guo, Yujuan Wang, "Research and Suggestions on the Construction of Green Belt and Road Initiative," Chinese Journal of Environmental Management, vol.3, pp. 15-19, 2017.

[5] Ran Jie, Jun Zhou, "Environmental Protection is the Best Background for the Belt and Road Initiative," Environmental Economy, vol.5, pp. 54-57, 2017.

[6] Luozhong Wang, Yijun Zhang, "The Environmental Protection Problems and Countermeasures of China's Overseas Investment in the Background of the Belt and Road Initiative," Chinese Journal of Environmental Management, vol.4, pp. 60-64, 2016.

[7] Hongkai Wang, "The Environmental Protection Problems and Countermeasures of China's Overseas Investment under the Belt and Road", Huaqiao University, 2017.

[8] Xiong Lee, "On Legal Risk of Environmental Protection in International Investment and Its Precaution", Hunan Normal University, 2013

[9] Min Zhang, Xueyan Zhu, “The Prevention of the Legal Risk of Chinese Enterprises' Foreign Investment in the Background of the Belt and Road

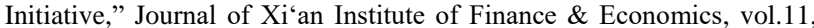
pp. 108-112, 2015.

[10] Zhangfeng Qiao, "The Risks and Prevention of Transnational Investment of Enterprises in the Background of the Belt and Road Initiative," Journal of International Economic Cooperation, vol11, pp. 72-74, 2017.

[11] Changjun Liao, Chengcai Zhou, "Analysis of Environmental Protection Problems and Countermeasures of China's Foreign Direct Investment," Future and Development, vol.7, pp. 27-31, 2010

[12] Chazhong Ge, Feng Long, "Research on Environmental Management in China's Foreign Investment," Environment and Sustainable Development, vol.4, pp. 23-26, 2011.

[13] Yi Yang, "Building the Green Belt and Road Initiative Should Grasp Three Key Problems," Regional Economic Review, vol.6, pp. 1-2, 2017.

[14] Feng Long, Chazhong Ge, Xiaohong Zhong, "Environmental Protection in China's Foreign Investment and Assistance," Environmental Protection, vol.1, pp. 66-68, 2009 